\section{The US military's environmental record under fire from Congress}

Washington

THE United States handling of hazardous and radioactive waste at its federal facilities has come under sharp attack from two different quarters.

A congressional subcommittee last week issued a report citing a long list of violations of federal hazardous waste laws by the US government at its Department of Defense (DoD) and Department of Energy (DoE) installations. A separate two-year study by a private organization describes a "massive radioactive contamination crisis" at DoE facilities which produce nuclear weapons.

The congressional report highlights several examples of federal noncompliance with environmental regulations. Among these are the Army's Picatinny Arsenal in New Jersey where trichlorethylene (TCE) has been found in groundwater at concentrations 5,000 times greater than the maximum acceptable concentrations set by the Environmental Protection Agency (EPA).

Also cited by the report is the McClellan Air Force Base in Sacramento, California, where similarly high levels of TCE as well as unacceptable levels of arsenic, barium, cadmium, chromium and lead have been found in a municipal well

\section{Europe wants more nuclear glasnost \\ London}

THE European Commission is increasing its pressure on member states to make information on their nuclear activities more widely available to the public to enable better planning in the event of an accident. The commission has proposed extending to the nuclear sector the principle already established for accident hazards at chemical plants, under which specific information is make available to the public on a regular basis, including details of any emergency plans that exist, and a register of hazards is maintained by the commission. Any similar measures applying to the nuclear sector would be introduced under the legislation on basic standards contained in the Euratom treaty.

The commission also wants to see a number of routine steps to be taken in the event of an emergency, including automatic notification of other member states likely to be affected.

The commissioner responsible for nuclear safety, Mr Stanley Clinton-Davies, hopes the new measures, if adopted, will go some way towards remedying the "woefully inadequate" information now available. Simon Hadlington area. Twelve nearby wells have so far been shut.

In addition to finding high levels of contamination, the report strongly criticizes the Defense and Energy Departments for their failure to comply with EPA clean-up orders. An example is the case of an Army installation in New Mexico, where nearly three years have elapsed with little or no action since cleanup was mandated.

Representative John Dingell (Democrat, Michigan), who chairs the House subcommittee that released the report, calls military facilities "among the worst violators of our hazardous waste laws,"

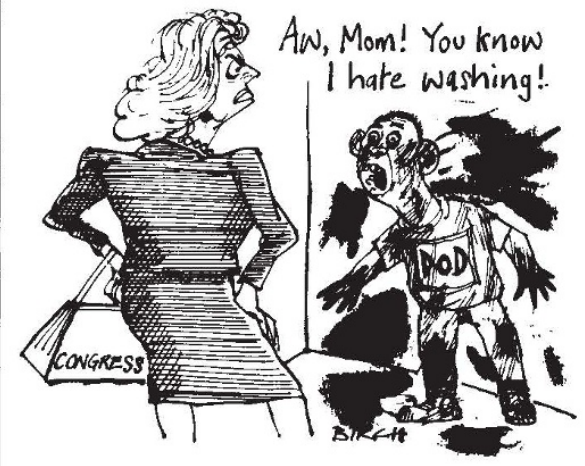

$$
\text { \%.S. MILHART- SHULMAN }
$$

and adds that "the [Defense] Department's attitude varies between reluctant compliance and active disregard for the law".

As the congressional report notes, EPA does not have the same influence on federal agencies as on private companies. Although the EPA's enforcement problems often involve Defense Department facilities, the report found similar noncompliance at DoE installations. For example, the Energy Department's nuclear fuel processing centre in Fernald, Ohio, is said to dump 109 million gallons of highly radioactive wastes into storm sewers illegally every year.

The report found that four years after uncovering such serious violations, DoE has yet to finish installing a groundwater monitoring system to analyse the extent of the problem.

Blatant violations of environmental laws at Energy Department nuclear facilities were the specific focus of a second report* issued last week by the Radioactive Waste Campaign, an environmental group based in New York. The group's study claims to be the first independent analysis of the environmental impact of the entire nuclear weapons complex.

Among the reported findings are that system that serves 23,000 people in the there are serious levels of radioactive pollution at all 16 of the major nuclear weapons production facilities in the United States, and that the total clean-up cost may be even greater than the Energy Department's estimate of $\$ 100,000$ million.

Seth Shulman

* Deadly Defense: Military Radioactive Landfills, Radioactive Waste Campaign, New York, June 1988.

\section{Ariane-4 launch finally to go ahead after setbacks \\ Paris}

AFTER a week of setbacks and last-minute repairs, the demonstration flight of Europe's new generation Ariane-4 commercial rocket launcher was scheduled to take place on 15 June at around noon GMT. Originally scheduled to lift off on 8 June, the prototype Ariane- 4 rocket developed problems with an on-board computer in the vehicle equipment bay and with the interface between payload and launcher. Onsite wiring repairs solved the interface problem, but parts of the computer had to be dismantled and sent to the manufacturers in France and Sweden. A new computer has now been installed and tests carried out at the launch pad in Kourou, French Guyana, are said by Arianespace - the European consortium operating Ariane to have been "completely satisfactory".

Ariane-4 is to be the 'workhorse' of Europe's commercial launches until the end of the century. With a backlog of 41 satellites, worth $\$ 2,290$ million to Arianespace, the company needs Ariane- 4 to come into service if it is to keep to its schedule of 8 launches per year. The advantage of Ariane- 4 over its predecessors is that it can carry heavier and more bulky payloads, permitting several satellites to be launched at once.

Arianespace won 50 per cent of world commercial satellite launch contracts when the US Challenger shuttle failed, only to find its own rockets grounded for over a year after a third-stage motor failure. With US commercial launches shortly to resume and with the Soviet Union, China and Japan eager to claim a share, Europe needs the demonstration flight of Ariane- 4 to go ahead without problems. But Arianespace is confident - in addition to twenty Ariane- 4 rockets currently being built, a further fifty have been ordered in order to cope with the consortium's target of $\mathbf{1 0 0}$ satellite launches from now to the year 2000.

Flight 401 will carry a payload of three satellites - a European weather satellite, Meteosat P2, and a US telecommunications satellite, Pan American Satellite-1, both to be put into geostationary orbit, and an amateur radio satellite, Amsat IIIC, to be put into an elliptical orbit. Peter Coles 